\title{
Cognition in Organizational Routines Research: a Systematic Review
}

\author{
Marlon Fernandes Rodrigues Alves \\ University of São Paulo \\ Federal Institute of Education, Science and Technology of São Paulo \\ Amanda Fernandes Rodrigues Alves \\ Federal University of the Triângulo Mineiro \\ Hélvio Antônio de Souza Júnior \\ Federal University of São Carlos \\ Simone Vasconcelos Ribeiro Galina \\ University of São Paulo
}

\begin{abstract}
The objective of this study is to systematically describe the extant research on cognition in organizational routines literature and to suggest future research opportunities. To achieve this objective, a systematic literature review was conducted. The studies included in the revision were classified and categorized into six dimensions: research context, research design, sector analyzed, research focus, cognition approach, and routines approach. Results map where further advances in the literature are still needed and the conflict of understandings among scholars. The main contribution of this study is linked to the recommendations that provide opportunities for future research.
\end{abstract}

Keywords: organizational routines; managerial cognition; decision-making; literature review.

\section{Resumo}

O objetivo deste estudo é descrever sistematicamente a pesquisa existente sobre a cognição na literatura de rotinas organizacionais e sugerir futuras oportunidades de pesquisa. Para alcançar esse objetivo, foi realizada uma revisão sistemática da literatura. Os estudos incluídos na revisão foram classificados e categorizados em seis dimensões: contexto da pesquisa, desenho da pesquisa, setor analisado, foco da pesquisa, abordagem da cognição e abordagem das rotinas. Os resultados mapeiam onde avanços na literatura ainda são necessários e o conflito de entendimentos entre acadêmicos. A principal contribuição deste estudo está ligada às recomendações que proporcionam oportunidades para pesquisas futuras.

Palavras-chave: rotinas organizacionais; cognição gerencial; tomada de decisão; revisão de literatura.

Área: 5.6 Transferência de tecnologia e Processos de aprendizado

JEL: B52, M10, D70, D83. 


\section{Introduction}

Organizational routines are at the center-stage of the research agenda in organizational theory since the works of Cyert and March (1963) and Nelson and Winter (1982) (Bygdas, 2017). Their contributions are the origins of two of the richest research fields in management literature of the past two decades: the organizational learning in organization studies, and the 'capabilities paradigm' in strategy (Gavetti, Greve, Levinthal, \& Ocasio, 2012). Nevertheless, organizational routines are yet easier to describe in terms of what they do than in terms of what they are since they encompass a complex phenomenon. One of the most accepted definitions is given by Feldman and Pentland (2003, p. 96) who conceptualize organizational routine as "a repetitive, recognizable pattern of interdependent actions, involving multiple actors."

The capability stream of research sees organizational routines as 'black box' and, therefore, tends to emphasize the automated or mindless trace of them (Parmigiani \& Howard-Grenville, 2011). Considering that organizational routines underlie continuous and endogenous change (Becker, 2004; Feldman, 2000; Lazaric, 2011), a second stream of research emphasizes the decision-making feature of them: routines are effortful accomplishments, where people chose between following, amending or changing an organizational routine (Feldman, 2000; Orlikowski, 2002; Pentland \& Rueter, 1994).

Understanding decision rules as organizational routines, imply a greater degree of mindfulness (Cyert \& March, 1963; Levinthal \& Rerup, 2006). This deliberative characteristic of organizational routines is in line with the distinction between the ostensive and performative aspects of organizational routines proposed by Feldman (2000) and Feldman and Pentland (2003): while the ostensive aspect take into account the 'cognition' of routines such as representation and intention, the performative denotes the actual performance. That is, the deliberated ostensive intent behind of routine may differ significantly from the performance accomplished.

However, although this ontology based on a duality of agency and structure denotes a complementary internal dynamic within organizational routines, the most significant contributions remain on the performative perspective (Becker, 2005; Cohen, 2007). As advocated by Dionysiou \& Tsoukas (2013), further the understanding of the ostensive (cognitive) aspect is on the base of at least two gaps in of organizational routines research. First, the paradox regarding how the relationship between the idiosyncratic aspects of individual cognitions translate into repeated patterns of actions in every instance (Cohen, 2007; Dionysiou \& Tsoukas, 2013; Gavetti et al., 2012; Parmigiani \& Howard-Grenville, 2011). Second, to understand the internal dynamics (ostensive/performative) of how routines are created and recreated across different levels (collective/individual) (Becker, 2005; Dionysiou \& Tsoukas, 2013; Parmigiani \& Howard-Grenville, 2011; Pentland \& Feldman, 2005).

Though, notwithstanding the potential benefits that further our understanding of cognition can bring to the organizational routine research, this topic has been only occasionally discussed in the literature (Cohen, 2007; Dionysiou \& Tsoukas, 2013). To our knowledge, no studies that attempted to syntheses the extant research of this theme have been identified so far, which leads to the research question of the present study: which studies address the cognition in organizational routines research?

Therefore, the aim of the current study is to systematically describe the extant research on cognition in organizational routines literature and to suggest future research opportunities. In order to achieve this objective, a systematic literature review was conducted based on previous literature reviews (Amui, Jabbour, de Sousa Jabbour, \& Kannan, 2017; Lage Junior \& Godinho Filho, 2010). Recent studies have shown an increasing interest in the role of 
managerial cognition, as can be seen in commemorative edition of the seminal paper of Porac, Thomas and Baden-Fuller (1989) (Kaplan, 2011), the microfoundation movement in strategic and organizational theory (Felin, Foss, \& Ployhart, 2015; Helfat \& Peteraf, 2015; Ployhart \& Hale, 2014) or the neuroscientific approach applied to decision-making in management (Laureiro-Martinez, Brusoni, \& Canessa, 2015; Laureiro-Martínez, Brusoni, \& Zollo, 2010). This work is structured as follows. After the introduction (Section 1), the methodological approach is presented (Section 2). Section 3 presents the findings followed by the conclusion (Section 4).

\section{Method}

\subsection{Methodological choice}

To provide useful insights into organizational routines and individual cognition, we used a systematic review (Tranfield, Denyer, \& Smart, 2003) to collate and interpret findings of published studies connecting both themes. A systematic review is a methodological strategic that derives knowledge from systematic categorization (Hakala, 2011). It is important because provides an overview of findings from published studies, characterizes emerging themes and identifies research challenges (Denyer, Tranfield, \& van Aken, 2008; Keupp, Palmié, \& Gassmann, 2012; Tranfield et al., 2003).

\subsection{Search strategy}

The systematic search was conducted on March 14, 2017. Eligible studies were identified using the Scopus and Web of Science (Social Sciences Citation Index) databases. The search included terms related to the two concepts: ('cognitive' OR 'cognition') AND ('organizational routines' OR 'organisational routines'). We search the field 'Topic' including 'Keyword plus' in the Web of Science and we search the fields 'Title', 'Abstract' and 'Keywords' in the Scopus. No limits of time were used during the online search.

\subsection{Inclusion and exclusion criteria}

During the selection process studies were included based on the following criteria: (i) they were published in English, (ii) they use the terms cognition and routines aligned with our conceptual background (quality criteria), and (iii) they were published through a peer-review process, even if is not a journal, such as the book series 'Advances in Strategic Management' (ISSN: 0742-3322). Both conceptual and empirical designs were included. Articles were excluded if they were conference abstracts, supplements, letters, editorials or books.

\subsection{Study screening and classification framework}

Figure 1 shows the flowchart of the study selection and screening process. 


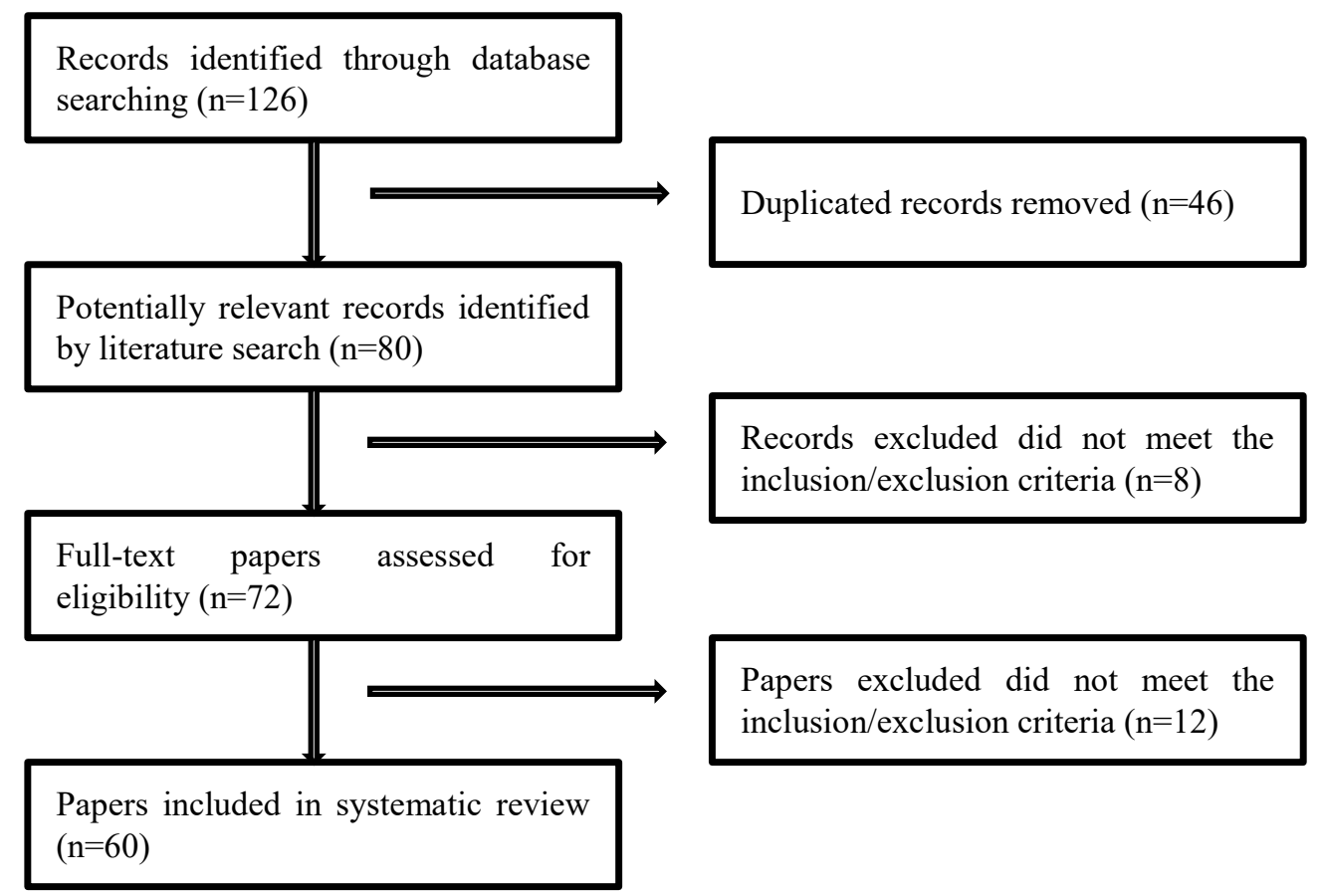

Figure 1. Flowchart of study selection process

The 60 studies included in the systematic review were published in the last 25 years. Figure 2 shows in the second half of the period a growth a higher publication of cognition in organizational routines research.

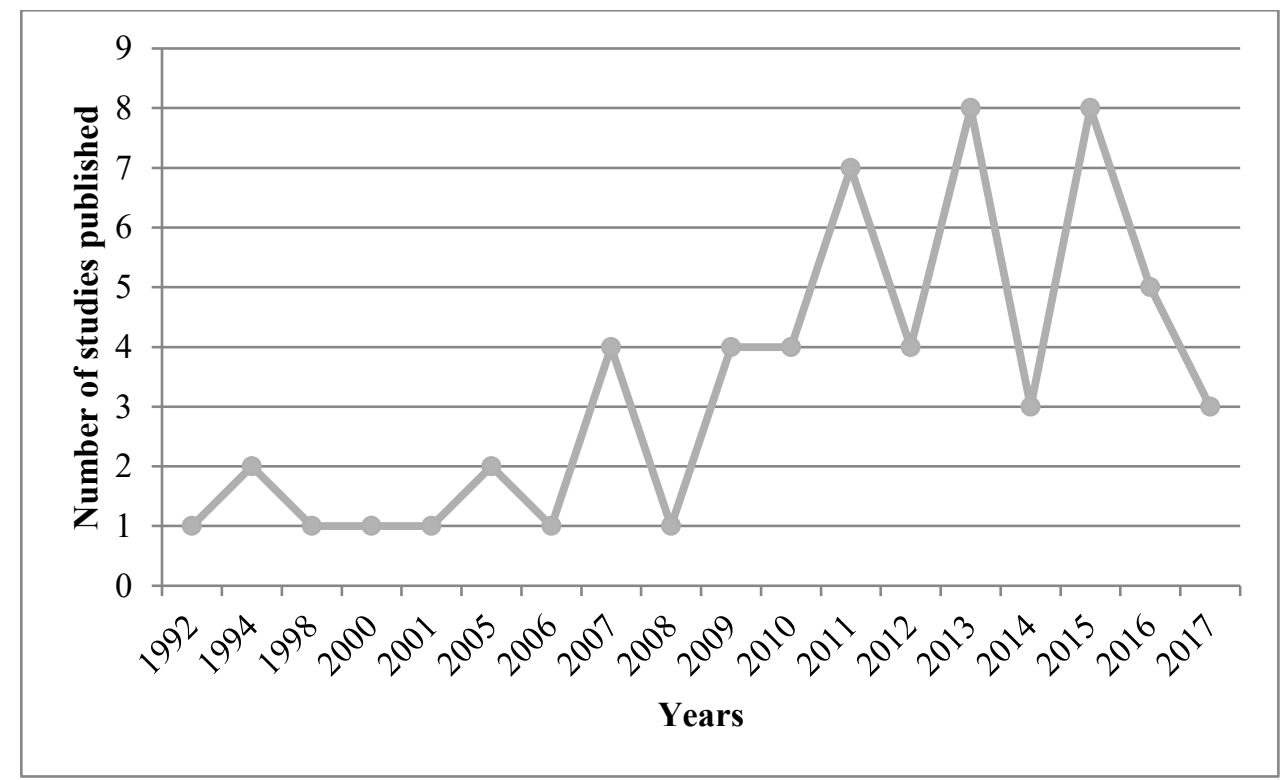

Figure 2. Publishing trend in this field of study

Two review authors independently screened the papers in three rounds (Heeks \& Bailur, 2007),. First, they assessed the title and abstract of potential records retrieved $(n=80)$ and, second, they check the content of full-text $(n=72)$, both against the inclusion/exclusion criteria. Third, they screened and categorized the eligible papers of the final sample that meet all the eligible criteria $(n=60)$ into a standardized template and cross-checked for accuracy. In the last round, a classification framework was developed to categorize the articles selected, 
using number and letter codes to classify the articles (Table 1). The classification dimensions were:

- National context analyzed (1), coded on an A-C scale (Lage Junior \& Godinho Filho, 2010)

- Research design used (2), coded on a scale of A-E (adapted Fiorini \& Jabbour, 2017).

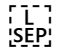

- Sector analyzed in the research (3), coded on an A-D scale (Fiorini \& Jabbour, 2017). [i]

- Main focus of research (4), coded A-D (i.e., whether the research totally focused on dynamic capabilities or was simply tangent to the dynamic capability theory) (adapted from Amui, Jabbour, de Sousa Jabbour, \& Kannan, 2017). SLEP

- Cognition approach (5), coded on an A-B scale (based on Gavetti et al., 2012). isẹp:

- Organizational routines approach (6), coded on an A-B scale (based on Ashforth \& Fried, 1988; Pentland \& Rueter, 1994). [isêp?

Table 1

Framework for classifying and coding the articles analyzed

\begin{tabular}{|c|c|c|}
\hline Classification & Meaning & Categories for coding \\
\hline \multirow[t]{3}{*}{1} & National context & A - Developed country \\
\hline & & B - Developing country \\
\hline & & C - Not applicable \\
\hline \multirow[t]{4}{*}{2} & Research design & A - Quantitative \\
\hline & & B - Oualitative \\
\hline & & $\mathrm{C}-$ Conceptualisep \\
\hline & & D - Reviewis \\
\hline \multirow[t]{3}{*}{3} & Sector analyzed & A - Manufacturing \\
\hline & & B - Services \\
\hline & & $\mathrm{C}$ - Others'sêpi \\
\hline \multirow[t]{4}{*}{4} & Main focus & A - Cognition \\
\hline & & B - Routines \\
\hline & & C - Both \\
\hline & & D - None \\
\hline \multirow[t]{2}{*}{5} & Cognition approach & A - Rational view \\
\hline & & $\mathrm{B}-$ Behavior view \\
\hline \multirow[t]{2}{*}{6} & Routines approach & A - Evolutionary patterns \\
\hline & & B - Effortful accomplishments \\
\hline
\end{tabular}

\section{Findings}

\subsection{National context}

Following the work of Fiorini and Jabbour (2017), Figure 3 shows that of those studies focusing in a particular national context, only two were in developing countries $(3,3 \%)$ : China and Malaysia (Bygdas, 2017; Yeo \& Gold, 2015). The remaining of the studies is divided between those ones in developed countries $(46,7 \%)$ or not applicable $(50 \%)$. This last category comprises the studies designed without a specific national context, such as conceptual articles (e.g. Cohen, 2007). Also, none of the studies compare countries from different levels of socioeconomic development. 


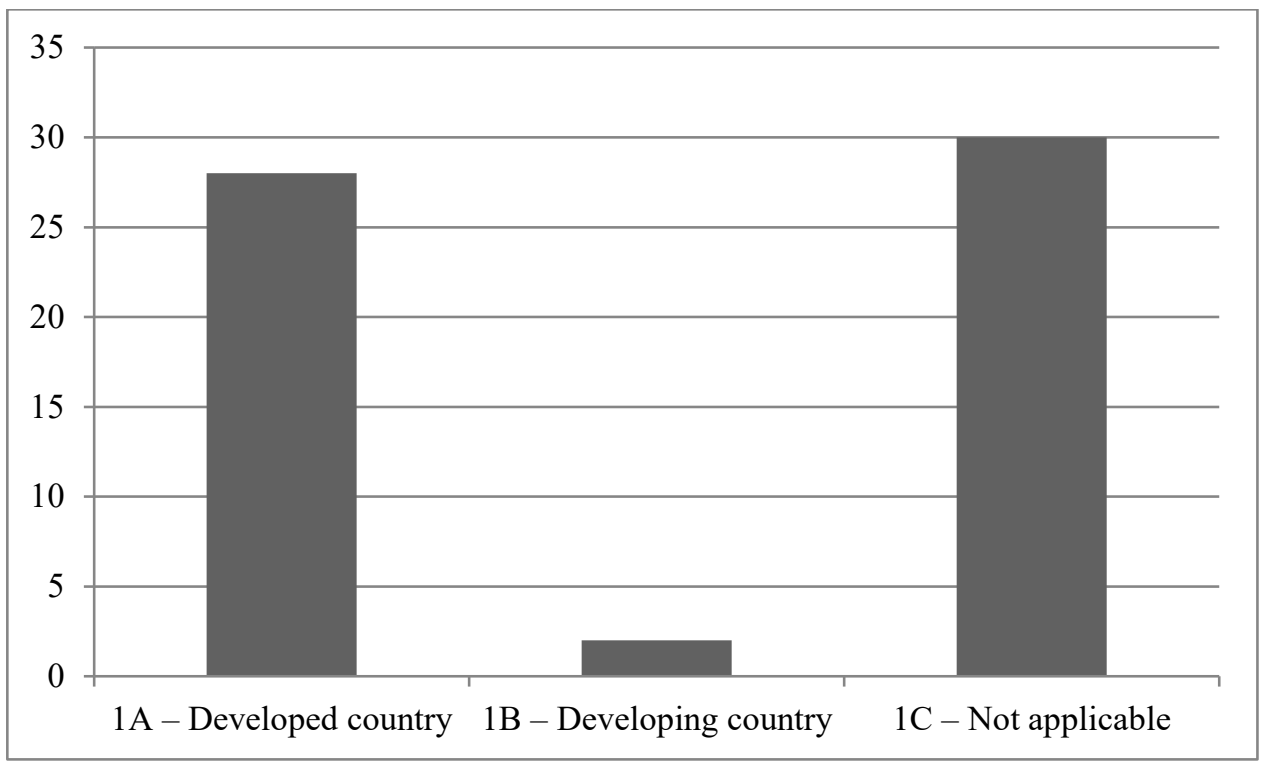

Figure 3. Frequency distribution of the category national context

This profile of research can suggest a bias because, for instance, the relationship between cognition and the environment is mutually dependent: cognition shape and is shaped by the environment (Porac et al., 1989). Even conceptual research could consider this issue more explicitly. Moreover, the national institutional framework as well the socioeconomic condition of countries affect the adoption and implementation of organizational routines (Massini, Lewin, \& Greve, 2005; Massini, Lewin, Numagami, \& Pettigrew, 2002). These findings led to the first recommendation of the present study:

R1: Conduct further studies in developing countries and design studies to compare countries with different profiles of socioeconomic development in order to understand how this affects the cognition in organizational routines.

\subsection{Research design}

The analysis indicates an overall balance between empirical works (quantitative or qualitative studies) and theoretical works (conceptual or reviews studies), each one accounting for $51,7 \%$ and $48,3 \%$, respectively. However, Figure 4 shows that the majority of research connecting the themes (cognition and organizational routines) is conceptual studies $(43,3 \%)$ followed by the qualitative studies $(38,3 \%)$. Only 8 studies were quantitative $(13,3 \%)$ and 3 were reviews $(5 \%)$. None of the works adopted mixed-methods. 


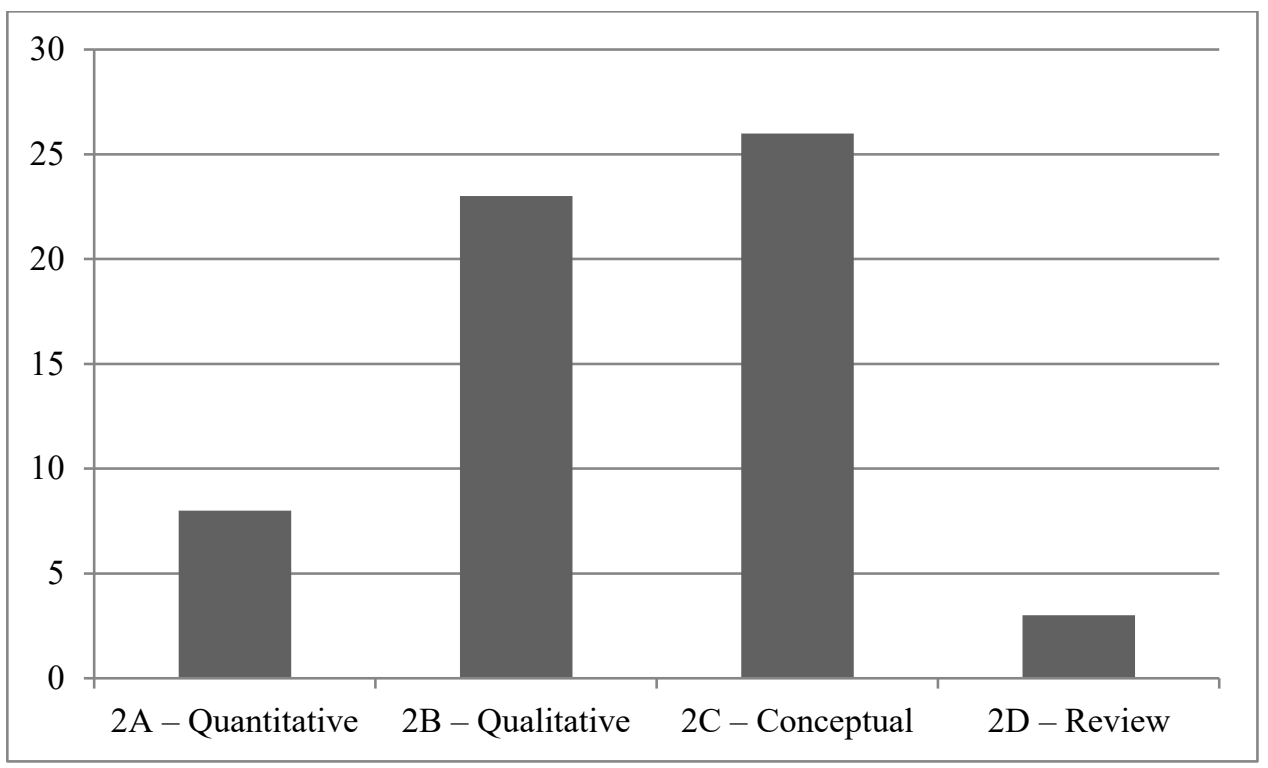

Figure 4. Frequency distribution of the category research design

It's worth to mention in terms of empirical setting the work of Paletz, Kim, Schunn, Tollinger and Vera (2013) who investigate cognition and team learning on two National Aeronautics Space Administration (NASA) mission to Mars. The study of Laureiro-Martínez et al. (2010) also deserves to be highlighted: she conducted a natural experiment design, which is not so usual in management research, due to the complexity of social science phenomena (Cooper \& Schindler, 2005).

The results suggest that more reviews and quantitative studies are still needed but, more important, there is space for researches integrating research methods by employing quantitative-qualitative or qualitative-quantitative study approaches. It's important to produce evidence from multiples methods to overcome method-variance in order to create a comprehensive theory (Spector, 2006). Therefore, the second recommendation of the present study is:

R2: Apply mixed methods approaches to study cognition in organizational routines research.

\subsection{Sector analyzed}

The results in Figure 5 show that while almost half of the studies delimitates the sector analyzed $(43,3 \%)$, the majority does not focus on a specific economic sector $(48,3 \%)$, such as conceptual studies or reviews. Among the studies that delimitate a sector, $16,7 \%$ focus in manufacturing companies and $26,7 \%$ in service companies. Finally, the 5 studies classified in category 3C (others) adopt multiples sector such as (Brauer \& Laamanen, 2014) or graduate student sample (Laureiro-Martínez et al., 2010), for example. 


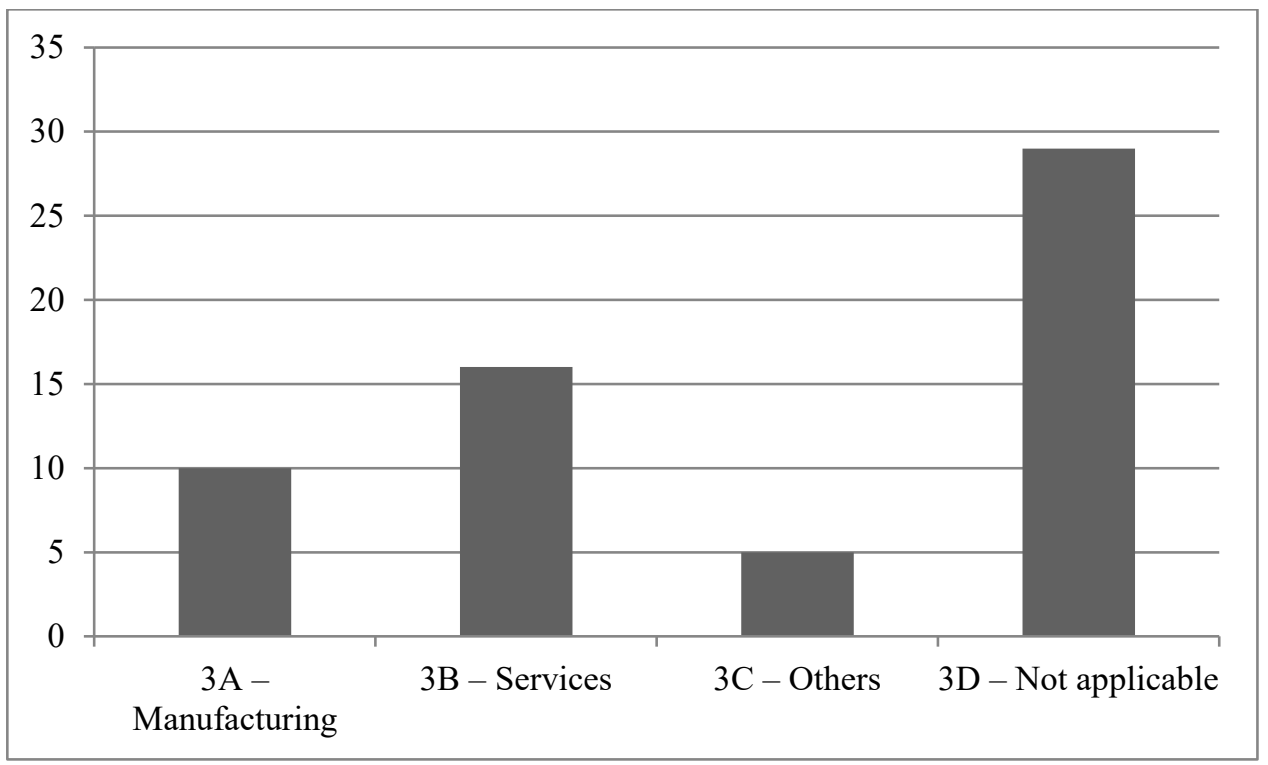

Figure 5. Frequency distribution of the category sector analyzed

While manufactures deals with operations where materials are the main resource to be processed, in service firms people (customer) are at the center of the organizational processes (Morris \& Johnston, 1987). This implies an accented relational feature on the organizational routines. Likewise, prior research already suggests differences in the adoption of new practices between different economic sectors (e.g. Prajogo, 2005). Accordingly, the third recommendation is:

R3: Conduct cross-sector studies to understand how the economic sector impacts the cognition in organizational routines.

\subsection{Main research focus}

The fourth categorization explores what is the primarily research focus of the studies (Figure 6). First, $41,7 \%$ of them focuses only on organizational routines, $30 \%$ focus straightforwardly on the relationship between cognition and organizational routines and, $15 \%$ just on cognition. The last 13,3\% addresses cognition and routines indirectly and focus on other themes such as behavioral theory (Gavetti et al., 2012) and organizational learning (Kump, Moskaliuk, Cress, \& Kimmerle, 2015). 


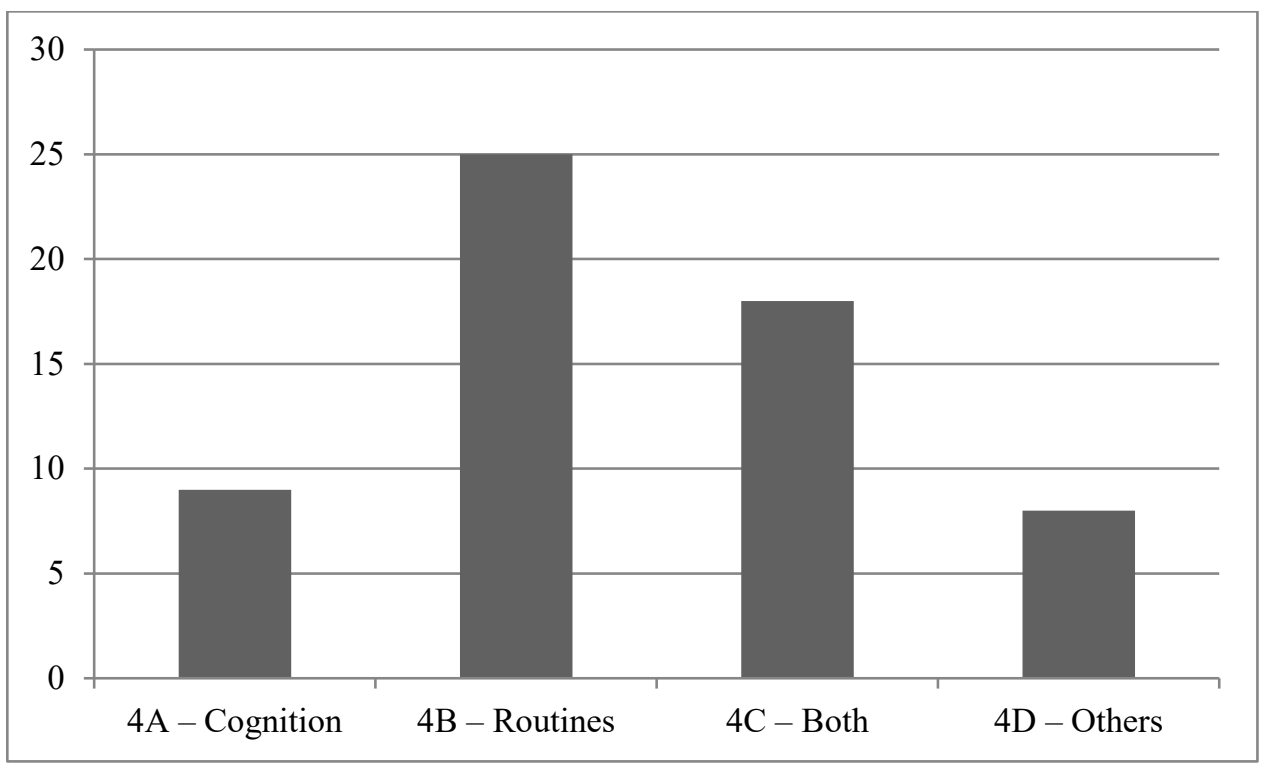

Figure 6. Frequency distribution of the category main research focus

This result reveals that is more frequent studies on routines encompassing cognition within its scope instead of studies on managerial cognition also incorporating organizational routines (e.g. Narayanan, Zane, \& Kemmerer, 2011). This fact reflects the novelty of the theme. But, more important, from those studies that offer some contribution to the understanding of cognition in organizational routines, only $30 \%$ had it as their main objective. Thus, the fourth recommendation is:

R4: Investigate in detail the role of cognition in organizational routine in order to integrate and harmonize the knowledge contributions of both research streams.

\subsection{Cognition approach}

Among those studies directly connecting the themes, Figure 7 shows that $16,7 \%$ adopts a rational view: an 'economic man' who decision-making process is based on rationality (e.g. Cabantous \& Gond, 2011). The remaining 83,3\% of the studies follows the Carnegie School tradition and adopts the bounded rationality condition (behavioral view). This stream encompasses in cognition research domains such as motivation, emotions, personal values, memory personality and ambitions (Cohen, 2007; Grodal, Nelson, \& Siino, 2015; Lazaric, 2011; Witt, 2011). 


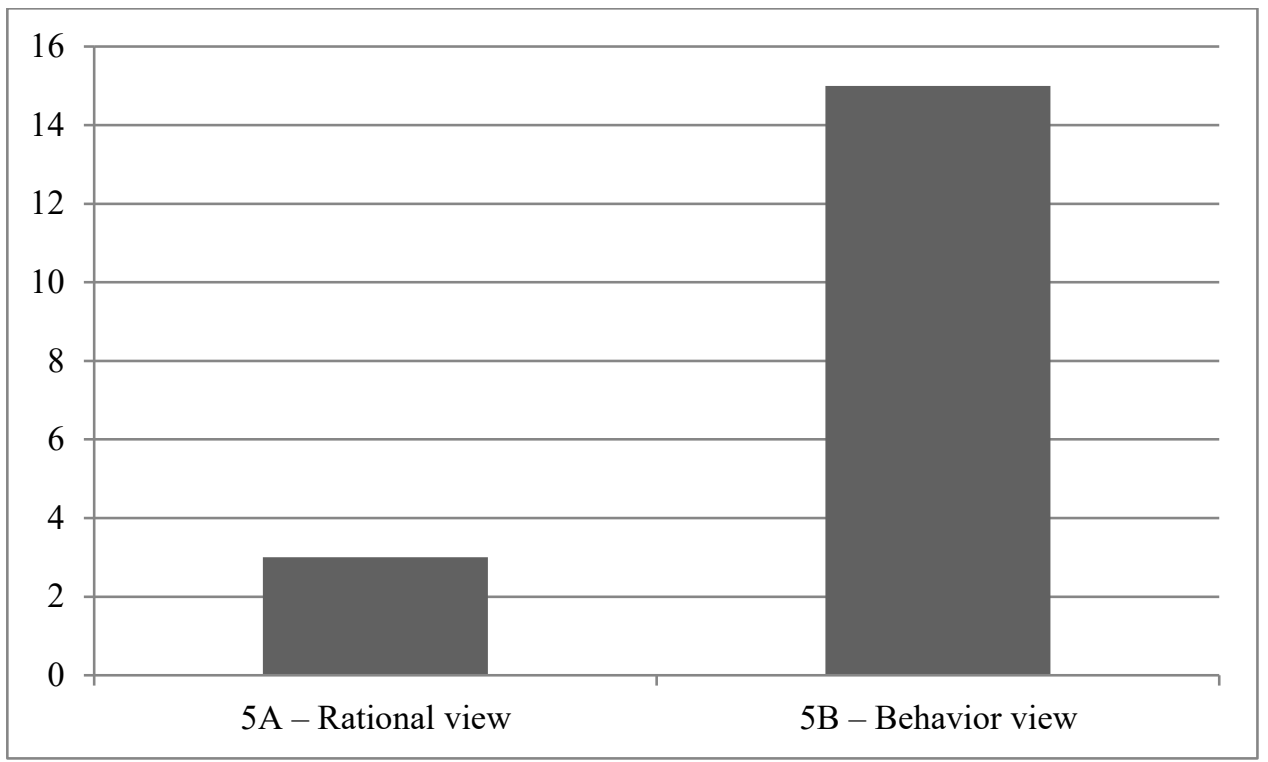

Figure 7. Frequency distribution of the category cognition approach

Rather than ask for more research in the rational view tradition, is consistent with the origin of the organizational routines concept to follow the behavior view. As stated by Gavetti et al. (2012, p. 4) "(...) decision makers lack perfect knowledge and must search for information, their actions are usually inconsistent with the maximization postulate of the rational agent model." In this sense, the fifth recommendation is:

R5: Conduct further studies to explore more domains of the cognition following the behavioral view.

\subsection{Routines approach}

Analyzing from the routines perspective, among the studies explicitly connecting the two themes, Figure 8 indicates that the majority of them $(83,3 \%)$ conceptualize organizational routines as effortful accomplishments. That is, implies in the routinized behavior a deliberative or intentional process (Lazaric, 2011). The others $16,7 \%$ of the works share a narrow understanding of routines as evolutionary patterns: rigid top-down procedures where changes are seen as deviations (de Boer \& Zandberg, 2012). 


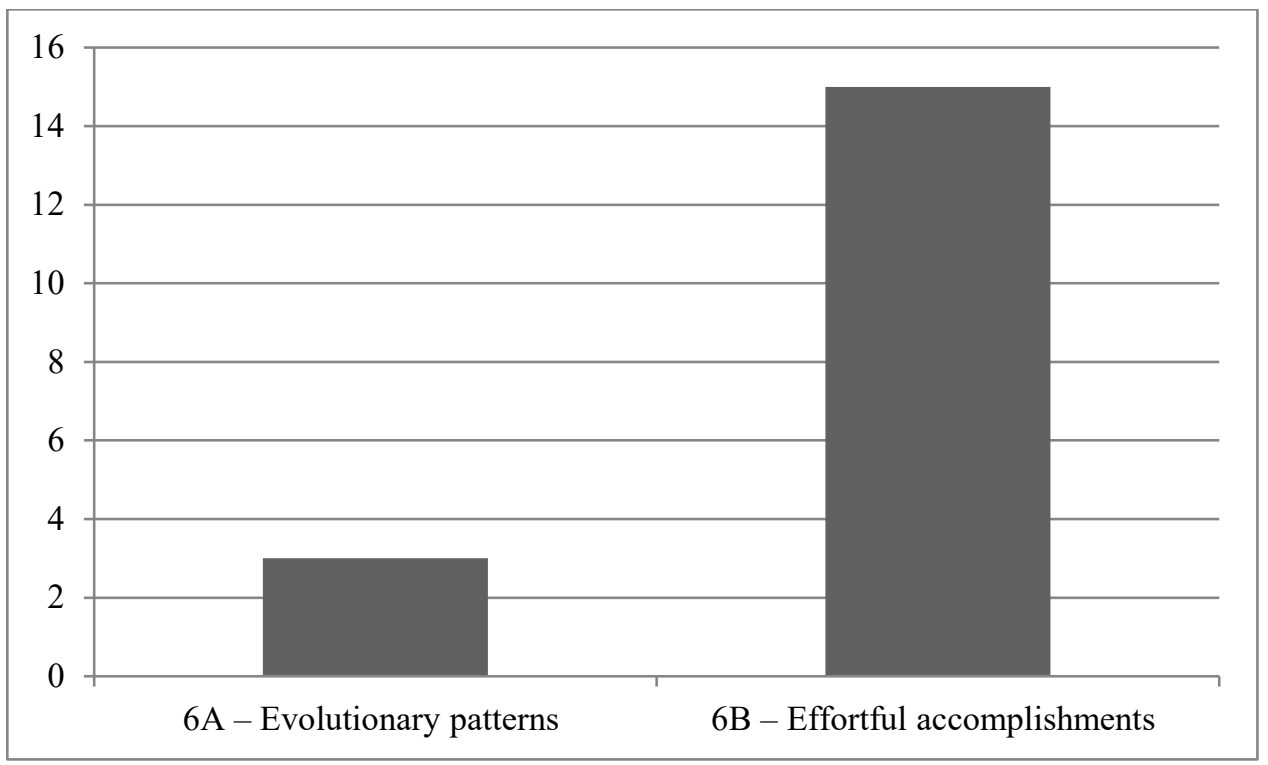

Figure 8. Frequency distribution of the category routines approach

Again, in the same way of Section 3.5 (Cognitive approach), this result is coherent with the calls to deepen the research on cognition in organizational routines (Dionysiou \& Tsoukas, 2013). Thus, this reflects a shift from the traditional approach of routines as fixed response to given stimuli, mindless rule-following or learned behavior towards a motivated and reflective practice capable of continuous, endogenous change. Hence, the sixth recommendation is:

R6: Investigate organizational routines addressing explicitly the assumptions of intention and deliberation.

\subsection{Cognition-routines relationship}

In order to explore how the literature had addressed the relationship between cognition and organizational routines, we undertake a content analysis to extract the conception behind this relation in each of the studies (Table 2). Only the papers directly addressing this relationship were selected (4C). This strategy seems to be more appropriate than to adopt preliminary categorization, what would reduce the richness of the data.

\section{Table 2}

Summary of the understandings

\begin{tabular}{|c|c|}
\hline$\underline{\text { Reference }}$ & Cognition-routines relationship \\
\hline $\begin{array}{l}\text { Aguilar-Zambrano \& Gardoni } \\
\text { (2011) }\end{array}$ & $\begin{array}{l}\text { Routines help to shape how the interaction between individuals and/or } \\
\text { organizations occurs. }\end{array}$ \\
\hline $\begin{array}{l}\text { Banks, Pollack, \& Seers } \\
(2016)\end{array}$ & Cognition is the building block of organizational routines. \\
\hline Cabantous \& Gond (2011) & $\begin{array}{l}\text { Routines overcome the limitations of individual rationality because are the sum } \\
\text { of individual experiences. }\end{array}$ \\
\hline Cohen (2007) & $\begin{array}{l}\text { Routines are living and dynamic elements because they encompass all the } \\
\text { characteristics of individual decision-making. }\end{array}$ \\
\hline Cohen \& Bacdayan (1994) & $\begin{array}{l}\text { Routines are a collective construction that emerges from a high level of } \\
\text { "procedural memory" of individuals. }\end{array}$ \\
\hline de Boer \& Zandberg (2012) & $\begin{array}{l}\text { Cognition breaks down the rigidity of routines generating deviations that can } \\
\text { increase adaptation as well as generate a loss of quality. }\end{array}$ \\
\hline Eggers \& Kaplan (2013) & $\begin{array}{l}\text { Routines and cognition are elements "co-constituted" that interact dynamically. } \\
\text { While routines may "naturally" emerge from patterns of cognition / decision- } \\
\text { making, is individual cognition that modifies established routines. }\end{array}$ \\
\hline
\end{tabular}


Grodal, Nelson, \& Siino (2015)

Johnson (2000)

Kieser \& Koch (2008)

Laamanen \& Wallin (2009)

Lazaric (2011)

Paletz et al. (2013)

Polites \& Karahanna (2013)

Stiles et al. (2015)

$\mathrm{Su}$, Brdiczka, \& Begole (2013)

Winter (2011)

Witt (2011)
Cognition and routines are interdependent. Routines can be established to modify the decision-making of individuals and favor certain behavior (look for and giving help, in the study). The establishing of routines should consider decision-making at the individual level while seeking to achieve the desired practice.

Planned routines need to be linked to daily experiences (present in the cognition) to impact organization performance; thus, cognition and planned routines complement each other.

Individual cognition operates on a rational and limited basis, are the routines that helps to overcome the limitations of rationality and interaction blocks (cultural visions, different goals) to produce new knowledge.

Managerial cognition has an important role in the choice of paths within the creation of new routines; further, cognition also plays an important role in the performative aspect of established routines.

Routines provide stability for daily activities and are modified both by external pressures and by internal pressures, which is characterized by individual decision-making.

Routines increase the efficiency of the processes and can be transferred to different situations, but cognition - as an adaptive expertise - can seek innovation together with efficiency by overcoming the limiting standards while seeking new solutions.

Routines are high-level patterns of coordination that undergo direct interference from individual habits. In situations of change, it is necessary to change the cognition of the individuals so that the change is integrated into the new routine.

The establishing of new routines goes through the screen of the individual cognition, which generates modifications and a "negotiation process". Therefore, in order to completely establish a new routine, attention must be given to individual motivation.

The individual cognition can impact the routine performance just as the routine itself ends up having effects on the cognition (e.g. stress).

There is an interaction between the two elements and the routine is very much based on cognition.

Routines have the potential to generate many benefits, but to access them; the mental model of individual cognition needs to be aligned with the objectives of the organization. Otherwise, the creation of routines will not bring benefits to the organization.

The results in Table 2 raise concerns with the lack of integration within the studies. More than different views, ontological divergences remain open: while some studies conceive cognition as a dimension of organizational routines (e.g. Grodal et al., 2015), others conceive cognition as a completely exogenous element from routines (Johnson, 2000). This kind of phenomenon among scholars can lead to the reification of the field, similarly to absorptive capacity research (Lane, Koka, \& Pathak, 2006). Therefore, the seventh recommendation is:

R7: Conduct further research on cognition in organizational routines following previous classical theoretical references.

\section{Conclusion}

This study aimed to present a systematic review of the research addressing cognition and organizational routines. This strategy of review has proven to be useful to structure the knowledge production and to direct avenues for future research (Amui et al., 2017; Keupp et al., 2012). To the best of our knowledge, this is the first study to systematize the relationship between cognition and organizational routines. 
To this end, a total of 60 studies published in the last 25 years were classified and coded to provide a comprehensive account of what has been published connecting the themes. Also, an overview of the main understandings of the relationship between cognition and organizational routines is provided. Finally, we presented seven recommendations to advance the field, which constitute a research agenda proposal.

More precisely, our recommendations offer opportunities to connect organizational routines research with the institutional theory to overcome some challenges in cross-country or crosssector studies (R1 and R3). In terms of method, our recommendations suggest the necessity of quantitative empirical studies, mixed-method and reviews (R2), which we partially address with this study. Concerning the main research focus, we show that if the research on routines still did not fully incorporate the cognitive aspect of them, studies on managerial cognition neglect the role of organizational routines almost completely. Therefore, we claim the importance of integrating both streams of research (R4).

The theoretical assumptions of the studies imply a progressive scenario where the lens of the behavioral view sees routines as intentional processes, thus, demanding a deeper understanding rather than a shift of paradigm (R5 and R6). Finally, our last recommendation is also the one that demands more attention: despite the accepted conceptualization of routines as a dual concept (performative and ostensive) and the behavioral view adopted by the studies, many of them are inconsistent with this premises and conceives cognition apart from routines. In face of that, we consider relevant for future research to design studies where managerial cognition is co-constituent of organizational (R7) because only by taking into account the dynamic and intrinsic relationship between them, the field can address the gaps in the extant literature.

This study contributes to the literature on both managerial cognition and organizational routines. Future studies may partially or fully apply the recommendations in order to close the gaps in the current literature and strengthen the state-of-the-art research. Advance in the research on the systemic cycling involving cognition and action in organizational routines can help to solve important issues in organizational theory, such as the emergence of a capability (Laamanen \& Wallin, 2009).

\section{References}

Aguilar-Zambrano, J. J., \& Gardoni, M. (2011). An information system to support problems definition based on technological frames and organisational routines. International Journal of Manufacturing Technology and Management, 22(3), 219-232. https://doi.org/10.1504/IJMTM.2011.039144

Amui, L. B. L., Jabbour, C. J. C., de Sousa Jabbour, A. B. L., \& Kannan, D. (2017). Sustainability as a dynamic organizational capability: a systematic review and a future agenda toward a sustainable transition. Journal of Cleaner Production, 142, 308-322. https://doi.org/10.1016/j.jclepro.2016.07.103

Ashforth, B. E., \& Fried, Y. (1988). The Mindlessness of Organizational Behaviors. Human Relations, 41(4), 305-329. https://doi.org/10.1177/001872678804100403

Banks, G. C., Pollack, J. M., \& Seers, A. (2016). Team coordination and organizational routines: bottoms up - and top down. Management Decision, 54(5), 1059-1072. https://doi.org/10.1108/MD-07-2014-0442

Becker, M. C. (2004). Organizational routines: a review of the literature. Industrial and Corporate Change, 13(4), 643-678. https://doi.org/10.1093/icc/dth026

Becker, M. C. (2005). Applying organizational routines in understanding organizational change. Industrial and Corporate Change, 14(5), 775-791. https://doi.org/10.1093/icc/dth071 
Bygdas, A. L. (2017). Patterns of Connectivity: The Enactment of Organisational Routines in Greenfield Projects. Knowledge and Process Management, 24(1), 38-52. https://doi.org/10.1002/kpm.1531

Cabantous, L., \& Gond, J.-P. (2011). Rational Decision Making as Performative Praxis: Explaining Rationality's Eternel Retour. Organization Science, 22(3), 573-586. https://doi.org/10.1287/orsc.1100.0534

Cohen, M. D. (2007). Reading dewey: Reflections on the study of routine. Organization Studies, 28(5), 773-786. https://doi.org/10.1177/0170840606077620

Cohen, M. D., \& Bacdayan, P. (1994). Organizational Routines Are Stored as Procedural Memory: Evidence from a Laboratory Study. Organization Science, 5(4), 554-568. https://doi.org/10.1287/orsc.5.4.554

Cooper, D. R., \& Schindler, P. S. (2005). Business Research Methods. McGraw-Hill Irwin.

Cyert, R. M., \& March, J. G. (1963). A behavioral theory of the firm. Upper Saddle River, NJ, US: Prentice Hall/Pearson Education.

de Boer, E. A., \& Zandberg, T. (2012). Decision-Making by Organizational Routines: The Influence of Agency and Personality Traits on Deviating from Formal Organizational Routines. Journal of Quality Assurance in Hospitality and Tourism, 13(4), 316-325. https://doi.org/10.1080/1528008X.2012.692287

Denyer, D., Tranfield, D., \& van Aken, J. E. (2008). Developing Design Propositions through Research Synthesis. Organization Studies, 29(3), 393-413. https://doi.org/10.1177/0170840607088020

Dionysiou, D. D., \& Tsoukas, H. (2013). UNDERSTANDING THE (RE)CREATION OF ROUTINES FROM WITHIN: A SYMBOLIC INTERACTIONIST PERSPECTIVE. Academy of Management Review, 38(2), 181-205. https://doi.org/10.5465/amr.2011.0215

Eggers, J. P., \& Kaplan, S. (2013). Cognition and Capabilities: A Multi-Level Perspective. Academy of Management Annals, 7(1), 295-340. https://doi.org/10.1080/19416520.2013.769318

Feldman, M. S. (2000). Organizational Routines as a Source of Continuous Change. Organization Science, 11(6), 611-629. https://doi.org/10.1287/orsc.11.6.611.12529

Feldman, M. S., \& Pentland, B. T. (2003). Reconceptualizing Organizational Routines as a Source of Flexibility and Change. Administrative Science Quarterly, 48(1), 94-118. https://doi.org/10.2307/3556620

Felin, T., Foss, N. J., \& Ployhart, R. E. (2015). The Microfoundations Movement in Strategy and Organization Theory. The Academy of Management Annals, 9(1), 575-632. https://doi.org/10.1080/19416520.2015.1007651

Fiorini, P. de C., \& Jabbour, C. J. C. (2017). Information systems and sustainable supply chain management towards a more sustainable society: Where we are and where we are going. International Journal of Information Management, 37(4), 241-249. https://doi.org/10.1016/j.ijinfomgt.2016.12.004

Gavetti, G., Greve, H. R., Levinthal, D. A., \& Ocasio, W. (2012). The Behavioral Theory of the Firm: Assessment and Prospects. Academy of Management Annals, 6, 1-40. https://doi.org/10.1080/19416520.2012.656841

Grodal, S., Nelson, A. J., \& Siino, R. M. (2015). Help-seeking and help-giving as an organizational routine: Continual engagement in innovative work. Academy of Management Journal, 58(1), 136-168. https://doi.org/10.5465/amj.2012.0552

Hakala, H. (2011). Strategic Orientations in Management Literature: Three Approaches to Understanding the Interaction between Market, Technology, Entrepreneurial and Learning Orientations: Orientations in Management Literature. International Journal 
of Management Reviews, 13(2), 199-217. https://doi.org/10.1111/j.14682370.2010.00292.x

Heeks, R., \& Bailur, S. (2007). Analyzing e-government research: Perspectives, philosophies, theories, methods, and practice. Government Information Quarterly, 24(2), 243-265. https://doi.org/10.1016/j.giq.2006.06.005

Helfat, C. E., \& Peteraf, M. A. (2015). Managerial cognitive capabilities and the microfoundations of dynamic capabilities. Strategic Management Journal, 36(6), 831850. https://doi.org/10.1002/smj.2247

Johnson, G. (2000). Strategy through a Cultural Lens: Learning from Managers' Experience. Management Learning, 31(4), 403-426.

Kaplan, S. (2011). Research in Cognition and Strategy: Reflections on Two Decades of Progress and a Look to the Future: Cognition and Strategy. Journal of Management Studies, 48(3), 665-695. https://doi.org/10.1111/j.1467-6486.2010.00983.x

Keupp, M. M., Palmié, M., \& Gassmann, O. (2012). The Strategic Management of Innovation: A Systematic Review and Paths for Future Research: Strategic Management of Innovation. International Journal of Management Reviews, 14(4), 367-390. https://doi.org/10.1111/j.1468-2370.2011.00321.x

Kieser, A., \& Koch, U. (2008). Bounded rationality and organizational learning based on rule changes. Management Learning, 39(3), 329-347. https://doi.org/10.1177/1350507608090880

Kump, B., Moskaliuk, J., Cress, U., \& Kimmerle, J. (2015). Cognitive foundations of organizational learning: re-introducing the distinction between declarative and nondeclarative knowledge. Frontiers in Psychology, 6, 1489. https://doi.org/10.3389/fpg.2015.01489

Laamanen, T., \& Wallin, J. (2009). Cognitive Dynamics of Capability Development Paths. Journal of Management Studies, 46(6), 950-981. https://doi.org/10.1111/j.14676486.2009.00823.x

Lage Junior, M., \& Godinho Filho, M. (2010). Variations of the kanban system: Literature review and classification. International Journal of Production Economics, 125(1), 1321. https://doi.org/10.1016/j.ijpe.2010.01.009

Lane, P. J., Koka, B. R., \& Pathak, S. (2006). The Reification of Absorptive Capacity: A Critical Review and Rejuvenation of the Construct. Academy of Management Review, 31(4), 833-863. https://doi.org/10.5465/AMR.2006.22527456

Laureiro-Martinez, D., Brusoni, S., \& Canessa, N. (2015). Cognition and Emotions in Exploration: A Deeper Look Into the Microfoundations of Strategic Change. Academy of Management Proceedings, 2015(1), 14079-14079. https://doi.org/10.5465/AMBPP.2015.14079abstract

Laureiro-Martínez, D., Brusoni, S., \& Zollo, M. (2010). The neuroscientific foundations of the exploration-exploitation dilemma. Journal of Neuroscience, Psychology, and Economics, 3(2), 95-115. https://doi.org/10.1037/a0018495

Lazaric, N. (2011). Organizational routines and cognition: An introduction to empirical and analytical contributions. Journal of Institutional Economics, 7(2), 147-156. https://doi.org/10.1017/S1744137411000130

Levinthal, D., \& Rerup, C. (2006). Crossing an Apparent Chasm: Bridging Mindful and LessMindful Perspectives on Organizational Learning. Organization Science, 17(4), 502513. https://doi.org/10.1287/orsc.1060.0197

Massini, S., Lewin, A. Y., \& Greve, H. R. (2005). Innovators and imitators: Organizational reference groups and adoption of organizational routines. Research Policy, 34(10), 1550-1569. https://doi.org/10.1016/j.respol.2005.07.004 
Massini, S., Lewin, A. Y., Numagami, T., \& Pettigrew, A. M. (2002). The evolution of organizational routines among large Western and Japanese firms. Research Policy, 31(8-9), 1333-1348. https://doi.org/10.1016/S0048-7333(02)00067-7

Morris, B., \& Johnston, R. (1987). Dealing with Inherent Variability: The Difference Between Manufacturing and Service? International Journal of Operations \& Production Management, 7(4), 13-22. https://doi.org/10.1108/eb054796

Narayanan, V. K., Zane, L. J., \& Kemmerer, B. (2011). The cognitive perspective in strategy: An integrative review. Journal of Management, 37(1), 305-351. https://doi.org/10.1177/0149206310383986

Nelson, R. R., \& Winter, S. G. (1982). An Evolutionary Theory of Economic Change. Harvard University Press.

Orlikowski, W. J. (2002). Knowing in Practice: Enacting a Collective Capability in Distributed Organizing. Organization Science, 13(3), 249-273. https://doi.org/10.1287/orsc.13.3.249.2776

Paletz, S. B. F., Kim, K. H., Schunn, C. D., Tollinger, I., \& Vera, A. (2013). Reuse and Recycle: The Development of Adaptive Expertise, Routine Expertise, and Novelty in a Large Research Team. Applied Cognitive Psychology, 27(4), 415-428. https://doi.org/10.1002/acp.2928

Parmigiani, A., \& Howard-Grenville, J. (2011). Routines Revisited: Exploring the Capabilities and Practice Perspectives. The Academy of Management Annals, 5(1), 413-453. https://doi.org/10.1080/19416520.2011.589143

Pentland, B. T., \& Feldman, M. S. (2005). Organizational routines as a unit of analysis. Industrial and Corporate Change, 14(5), 793-815. https://doi.org/10.1093/icc/dth070

Pentland, B. T., \& Rueter, H. H. (1994). Organizational Routines as Grammars of Action. Administrative Science Quarterly, 39(3), 484. https://doi.org/10.2307/2393300

Ployhart, R. E., \& Hale, D. (2014). The Fascinating Psychological Microfoundations of Strategy and Competitive Advantage. Annual Review of Organizational Psychology and Organizational Behavior, 1(1), 145-172. https://doi.org/10.1146/annurevorgpsych-031413-091312

Polites, G. L., \& Karahanna, E. (2013). The embeddedness of information systems habits in organizational and individual level routines: Development and disruption. MIS Quarterly: Management Information Systems, 37(1), 221-246.

Porac, J. F., Thomas, H., \& Baden-Fuller, C. (1989). COMPETITIVE GROUPS AS COGNITIVE COMMUNITIES: THE CASE OF SCOTTISH KNITWEAR MANUFACTURERS. Journal of Management Studies, 26(4), 397-416. https://doi.org/10.1111/j.1467-6486.1989.tb00736.x

Prajogo, D. I. (2005). The comparative analysis of TQM practices and quality performance between manufacturing and service firms. International Journal of Service Industry Management, 16(3), 217-228. https://doi.org/10.1108/09564230510601378

Spector, P. E. (2006). Method Variance in Organizational Research: Truth or Urban Legend? Organizational Research Methods, 9(2), 221-232. https://doi.org/10.1177/1094428105284955

Stiles, P., Trevor, J., Farndale, E., Morris, S. S., Paauwe, J., Stahl, G., \& Wright, P. (2015). Changing Routine: Reframing Performance Management within a Multinational. Journal of Management Studies, 52(1), 63-88. https://doi.org/10.1111/joms.12111

$\mathrm{Su}$, N. M., Brdiczka, O., \& Begole, B. (2013). The Routineness of Routines: Measuring Rhythms of Media Interaction. Human-Computer Interaction, 28(4), 287-334. https://doi.org/10.1080/07370024.2012.697026 
Tranfield, D., Denyer, D., \& Smart, P. (2003). Towards a Methodology for Developing Evidence-Informed Management Knowledge by Means of Systematic Review. British Journal of Management, 14(3), 207-222. https://doi.org/10.1111/1467-8551.00375

Winter, S. G. (2011). Problems at the Foundation? Comments on Felin and Foss. Journal of Institutional Economics, 7(2), 257-277. https://doi.org/10.1017/S1744137410000470

Witt, U. (2011). Emergence and functionality of organizational routines: An individualistic approach. Journal of Institutional Economics, 7(2), 157-174. https://doi.org/10.1017/S1744137410000226

Yeo, R. K., \& Gold, J. (2015). More than meets the eye: working around technology in crossboundary work contexts. Information Technology \& People, 28(3), 623-652. https://doi.org/10.1108/ITP-05-2013-0091 